HISTORY OF MEDICINE

\title{
Caring for "incurables": the 150th anniversary of the Royal Hospital for Neuro-Disability, Putney
}

\section{G C Cook}

Postgrad Med J 2004;80:426-430. doi: 10.1136/pgmi.2003.017673

The Royal Hospital for Incurables (RHI), now known as the Royal Hospital for Neuro-Disability and situated on West Hill, Putney, was founded by Andrew Reed DD exactly 150 years ago. The RHI was thus the pioneer in modern times of long stay institutions for the sick and dying. It became one of the great Victorian charities, and remained independent of the National Health Service, which was introduced in 1948. Originally the long stay patients suffered from a multiplicity of diseases; in recent years chronic neurological disease has dominated the scenario. This institution has also become a major centre for genetic and traumaassociated neurological damage, and rehabilitation.

Correspondence to:

Professor Gordon C Cook, Fellowship of Postgraduate Medicine, 12 Chandos Street, London W1G 9DR, UK

Submitted

1 December 2003

Accepted

17 December 2003
O riginally founded as the Royal Hospital for Incurables (RHI) in $1854^{1-5}$ the name of this institution was changed in 1917 to the Royal Hospital and Home for Incurables (RHHI), and in 1919 a Royal Charter was at last granted. Recently, the name was again changed to the Royal Hospital and Home, Putney (1982) and to the Royal Hospital for Neuro-Disability (1995).

\section{THE ORIGIN AND THE SITE}

The RHI was the fifth and last of the charities founded by one of the great 19th century philanthropists, Andrew Reed (1787-1862), ${ }^{26}$ a non-conformist minister who obtained an honorary doctorate in divinity in the USA (fig 1).

His four preceding charities were:

- The London Orphan Asylum, 1813.

- The Infant Orphan Asylum, 1827.

- The Asylum for Fatherless Children (the Reedham Orphanage), 1843.

- The Asylum for Idiots, 1847.

All, except the "Asylum for Idiots", remain extant.

The situation regarding incurables, or long stay patients, in 1854 was that if poor they were cared for at the workhouse infirmary. ${ }^{78}$ If they were not paupers, they were not eligible for long term accommodation in either the local hospitals, or the great voluntary general hospitals of London-for example, St Thomas's, Guy's, St Bartholomew's, and the (Royal) London. Those were primarily curative institutions, and as laid down in their charters they could not, and would not, admit incurables.

London, and in fact Britain lacked, in 1854, an institution designed specifically for the long term care of these unfortunate individuals. This fact had been made clear in Household Words in 1850. This weekly journal, with Charles Dickens (1812-70) as its editor, considered:
"It is an extraordinary fact that among innumerable medical charities with which this country abounds, there is not one for the help of those who of all others [that is, the "incurables"] most require succour ...".

It is probable that Dickens was merely reflecting (as he often did) the popular opinion of the time. In any event, Dickens took a keen interest in Reed's initiative and presided at the first two charity dinners, the prime object of which was to raise much needed funds for this unique venture. It seems possible that Reed had based his underlying philosophy on that of John Howard (1726?-90), ${ }^{6}$ the great 18th century philanthropist.

Obviously, siting of the new charity was important. Reed had already founded the Asylum for Fatherless Children at Coulsdon, Surrey (see above), and it seemed appropriate to establish the RHI in that locality, which being well away from London (the "great wen") was relatively free of miasmas. An old workhouse at Carshalton (north of Epsom) provided the first (temporary) home of the RHI. Although it served to get the hospital established, it was inadequate on many counts, not least its very limited space, which precluded expansion. After three years therefore, the Board of Management decided that a more commodious venue was required, and the RHI was moved to Putney House (now demolished) in Richmond (now Upper Richmond) Road. Shortly afterwards an annexe had to be found for the expanding patient numbers.

Reed, together with some members of the Board of Management, remained strongly in favour of a site at Coulsdon for the definitive building. He, and his supporters, invited the views of several leading authorities on hospital design-including Florence Nightingale (18201910) —an enthusiast for the "pavilion" plan," and still regarded by the public as the heroine (the "Lady with the Lamp") of the Crimean War (1853-56), which the bulk of the population had not wanted, and which had in fact decimated the British Army. However, a significant proportion

Abbreviations: RHI, Royal Hospital for Incurables; RHHI, Royal Hospital and Home for Incurables 


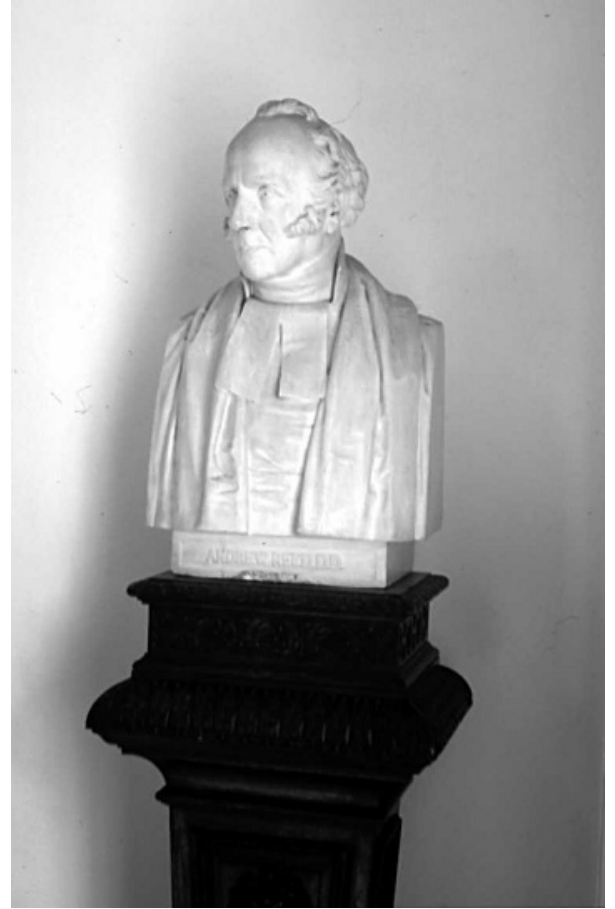

Figure 1 The founder of the RHI, the Reverend Dr Andrew Reed (17871862). The bust by J H Foley, RA, is now in the entrance hall of the Royal Hospital for Neuro-Disability.

of Reed's Board considered the Coulsdon site unsatisfactory. Among their reasons were:

- 'The situation [was] too high and exposed for several classes of the patients ...

- The situation [was] unsheltered by trees, the surface of the ground [was] irregular ... and

- The distance from London and Croydon [was] inconvenient ...

As a sequel, a number of the Board (including the chairman and Treasurer, Viscount Raynham (1801-76), and one of the vice Presidents, the third Marquess Townshend (1778-1855) resigned, and immediately founded the British Home for Incurables at Clapham (it is now situated at Streatham). All ideas of Coulsdon as an ultimate venue were thus abandoned, and a satisfactory site elsewhere was urgently sought.

Eventually Melrose Hall, West Hill, Putney (fig 2) was settled upon. This had been built by John Rucker in 1796. A former house, situated on this land which had been carved out of the estate of the first Earl Spencer at Wimbledon Park had been built by Lady Rivers and subsequently became the property of the seventh earl of Stormont (1727-96). The grounds of Spencer's estate had been landscaped by the leading exponents of the day-including Lancelot Capability Brown (1716-83). Reed sadly (or possible fortunately) did not live to see the removal of the RHI to Melrose Hall. He died in 1862, and the removal (the house had been bought by the RHI in 1863) took place in 1864-5. In the same year that the charity bought Melrose Hall from John Beaumont (1806-86), the Lord Bishop of Winchester (Samuel ["Soapy Sam"] Wilberforce, 1805-73) consecrated the newly erected church of the Holy Trinity, which has throughout most of the last 150 years been a close neighbour of the RHI. Wilberforce, when Bishop of Oxford, had been the main opponent of The Origin of Species by Natural Selection, or the Preservation of Favoured

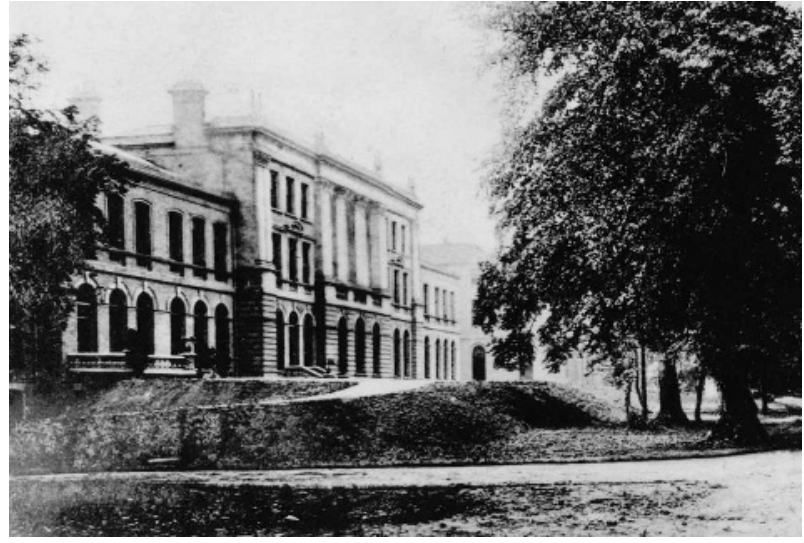

Figure 2 The RHI in 1905. The façade as seen from Putney West Hill is not the original Melrose Hall building, but the great extension of 187981.

Races in the Struggle for Life (published in 1859) by Charles Darwin (1809-82).

\section{Extensions to Melrose Hall}

Since Melrose Hall became the home of the RHI, a number of wings (extensions) have been added. The original house (which incorporates the main entrance hall today) was a relatively small building. North (1864) and south (1868) wings were soon added, and the great extension (forming the main northern façade, facing West Hill) was built between 1879 and 1881 . This brought with it a new bakery and dining room, kitchen, and offices. The Prince of Wales (later King Edward VII) (1841-1910) laid the foundation stone, and the opening ceremony was performed by the Duke of Connaught and Strathearn (1850-1942).

The Restell Wing was added in 1901 to the east of the great extension. A few years later, in 1909, the widow of General Edward de Lancey Lowe (1820-80) (she had subsequently remarried) left in her will a sum sufficient to enable the RHI to build the de Lancey Lowe room, which lies to the south of the great extension of 1879-81, and like the Assembly room, serves as a multipurpose room in the hospital today. This room was opened in 1909. Before the Assembly room was built, the lady inmates had used what today is the library, and the male equivalents had the use of the north wing.

The original lifts in the great extension were worked by hand; they were succeeded by hydraulic, and in 1909 electric ones. In 1892, a new laundry had been added. In 1930, the dining rooms were extended outwards towards the road; the men's room was merged into that of the ladies. Recently several newer extensions, in very different architectural styles, have been added: Chatsworth (to the west of the main building) (1976), Alexandra (1980) and Drapers (1985) (to the east), and Goodman House (1997) to the south east.

A notable addition to the hospital was the nurses' home, situated in close proximity to Holy Trinity Church. Although it had been decided as early as 1919 to build a nurses' home (nurses had until then lived in the main hospital building), this scheme was abandoned due to lack of funds, and instead two houses were rented in West Hill. The original scheme was later resurrected, and the Duchess of York (subsequently the Queen, and then the Queen Mother) (1900-2002) opened the nurses' home in 1935.

Purchase of the Melrose Hall estate in 1863 brought with it a farm (which was situated in the hospital grounds, close to the site now occupied by Goodman House). This originally contained livestock-cows, sheep, pigs, and poultry-the produce providing valuable sustenance for the inmates of the 
charity. Later, an orchard was incorporated. Supervision of the farm was undertaken from 1865 for a period of 50 years by John Thatcher. Sadly, all farming activities came to an end around 1930.

Late in the 19th century in a new venture, Seaside House was initiated at St Leonard's-on-Sea. This survived for 17 years from 1885, and was a seaside retreat for inpatients (and later pensioners also) of the RHI. It was in certain respects similar to John Howard house, a property renovated in Brighton in 1974 and sold some 25 years later.

\section{PATIENT CARE}

The inpatients, originally termed inmates, suffered from a miscellany of chronic diseases, but more recently neurological disease-especially multiple sclerosis-has come to the fore. The outpatients, distributed all over the country, were initially designated pensioners. In the very early days, the family was used as a descriptive term for the inmates; it is likely that Reed himself had introduced that term.

Originally there was no regular doctor, and the RHI employed a junior practitioner who was regularly on-call and had to provide and dispense drugs out of his own earnings! A dispenser was later employed. There have been a number of junior doctors over the years, but there were two very long serving practitioners: Drs Thomas James Woodhouse and John Gay, who served for 35 and 31 years, respectively, between 1866 and 1932. There were also the visiting consultant staff (both physicians and surgeons), many of whom were both leaders of, and eminent in the medical profession. The original consultant physicians were William Little (1810-94) ${ }^{10}$ and William Munk (1816-98), ${ }^{11}$ and the consulting surgeon was James Luke (1799-1881). ${ }^{12}$ Moves to appoint a resident medical officer, which was demanded by several bodies, including a House of Lords Select Committee (which was set up to report on the Metropolitan Hospitals), have repeatedly failed.

In the early days of the charity, nursing was surprisingly relatively neglected, there being a mere three day and one night nurses. Nursing was not then considered a respectable profession $^{12}$; Dickens had, for example, portrayed Sairey Gamp in Martin Chuzzlewit as a nurse typical of that era. By 1878 a system of divisional nurses, or Sisters was introduced. Beneath them were assistant nurses and attendants. The longest serving matron was Mrs Linicke-by birth a German and known to Florence Nightingale (see above) who advised on her strengths and weaknesses before she was appointed in 1881. She retired in 1903 at the age of 70 years. Miss Lucy Begg later held the post for 31 years.

The religious life of patients (inmates) has traditionally been important. The Royal Hospital for Neuro-Disability has never possessed a chapel matching that at the British Hospital for Incurables at Streatham, and for much of the hospital's existence, there was not a regular chaplain. When requested to become president of the RHI like his two immediate predecessors (Charles Thomas Longley [17941868] and Archibald Campbell Tait [1811-82]), Archbishop Edward White Benson (1829-96) pointed out the inadequacies of pastoral care at the RHI, and the Board were therefore compelled to look elsewhere for a new president. It was not until 1903 that the RHI had its own chaplain. Charity sermons have been preached from the earliest days of the RHI and overall they have raised considerable sums-greatly valued, as the hospital has never received support from the Metropolitan Hospital Sunday Fund, or the King's Fund for London. $^{35}$

\section{THE PATIENTS' LOT!}

There had, especially in the early days, been careful "monitoring" of alcohol (or "stimulant") consumption.
This probably dates to the non-conformist background of the institution. Although alcoholism associated with excessive gin consumption is primarily an 18th century phenomenon-typified by the depiction of gin parlours by William Hogarth (1697-1764) — the evils associated with excessive indulgence lurked on well into the 19th century. The major donor of champagne seems to have been the hospital treasurer, Henry Huth! The medical officer and one of the visiting physicians were given the task of advising on a healthy allowance of "stimulant". In 1860, it was recommended by them that wine and spirits should not be consumed in the summer months! In 1858, 1 1/2 pints of malt liquor was consumed daily by the patients and staff, and a year later 23 glasses of wine were consumed each day. Two decades later, the allowance of beer for the attendants was reduced from three to two pints daily.

In 1880 the male staff had their supply of claret discontinued, although the matron was allowed to provide it to certain nurses at her discretion. A few years later excessive use of ale and port wine was also discontinued, and subsequently an allowance of 50/- per annum in lieu of alcoholic beverage for the staff was imposed; by 1889 the entire staff had opted for "beer money" rather than alcohol. The beer allowance for patients was also reduced to one glass at dinner and one at supper; the male patients seem to have protested at this! Despite the monitoring of stimulant consumption by patients, drunkenness among both staff and patients seems to have been relatively uncommon, and over the years, alcoholism at the RHI has become a relatively rare occurrence. $^{3}$

Patient entertainment was always a high priority. Early in the history of the RHI, the Goldschmidts lived in the vicinity of Melrose Hall (at Parkside); Otto was an accomplished pianist, whereas his wife-better known as Jenny Lind (1820-87), "the Swedish nightingale" —was a renowned singer. Both she and Lady Jenkinson regularly gave concerts to raise funds. Sir Squire Bancroft, a well known and highly talented actor, read Dicken's "Christmas Carol" and this too raised funds for the RHI. ${ }^{35}$

Local concerts and dramatic performances also took place, and by the end of the 19th century several were taking place every month. Another great entertainer, who subsequently became a patient at the RHHI, was the celebrated magician, David Devant. Other fundraising events have included garden parties, fêtes, and firework displays. Another occasion, organised by the Lady Visitors, was the annual sale of (patients') work. These occasions which were opened by individuals who were prominent in public life-often duchesses-lasted for three days. One year, Lady Gowers, a grand-daughter of Reed, opened this event. ${ }^{35}$

\section{MANAGEMENT AND THE ELECTION (VOTING) SYSTEM}

The institution has in the past often been criticised for managerial flaws. ${ }^{35}$ It is appropriate therefore to outline the way(s) in which the hospital has been run over the last 150 years.

The patron has always been a member of the Royal Family. On many occasions, two or even three members have served simultaneously in this capacity. The President has usually been a peer of the realm, and in two instances, Archbishops of Canterbury have filled this position (see above). Until 1911, the offices of Chairman and Treasurer were combined. In the 19th and early 20th century, Henry Huth served in this dual capacity for a period of 17 years, and the Allcrofts (father and son) for a total of 31 years in all. But, crucial to the running of the hospital has always been the Secretary. The first Secretary, Frederic Andrew (commemorated by the Andrew Day Room) served for 46 years. A successor was 
Charles Cutting (from the Royal Free Hospital) who filled this position for 31 years before resigning in 1937.

Until immediately after the Second World War (1939-45) it was, like most other charities, run from a City (of London) office. In the early days, city contacts were important, and all events, board meetings (which traditionally took place monthly), annual general meetings, elections, dinners, receptions, etc took place there. In the early days one of the City clerks was designated the collector; James Best served in this capacity for 36 years. The position was abolished in 1905. His principal duty was to collect subscriptions.

The lowest age for admission has changed throughout the years; initially it was 16 , then 20 , later increased to 30 years and now 18. It was not uncommon to transfer patients from the pension list to that of "inmates".

From the outset, admission as an "inmate" or "pensioner" was based on a voting system. On payment of a certain sum, an individual was allowed a prescribed number of votes. Clearly, this brought valuable financial income to the charity, but unless a potential patient knew or could persuade a governor to vote for him or her, there was no chance of success at the biennial election. As a result, many deserving individuals did not gain sufficient votes. Despite criticism from many quarters including the House of Lords Select Committee, this system survived for about a century. In the early days payment from patients (or their relations or friends) was acceptable-for example, $£ 20$ or $£ 50$ per year. From the earliest times various methods were tried to assist those who had failed in the election(s).

Most controversies took place in the 19th century, and the majority were targeted at the management (see above). In 1867, the Athenaeum (a widely read weekly journal) was critical of Melrose Hall (which it considered was not an appropriate building to house the hospital), the lack of a resident doctor, and the absence of a Ladies Committee. But it later transpired that the informant for this article was himself a member of the Board of Management of the RHI, the Reverend William Woodhouse. In 1872, the Charity Organisation Society was highly critical of the voting system (see above); the Athenaeum joined the fray, re-kindling its former charges! In 1892 (that is, 20 years later) a Select Committee of the House of Lords (see above) criticised the management on much the same grounds as the Athenaeum, with the addition that all nurses-they claimed-should be hospital trained. An internal inquiry at the RHI attempted to negate these criticisms but stuck to its guns. The only major criticism since this was in 1927 when Truth (another periodical) published a somewhat critical article surrounding the suicide of an RHHI patient. ${ }^{5}$

\section{RÔLE OF WOMEN}

From the foundation of the charity, women have always played a major part in running the hospital. However, the 19th century was not a time when women were expected, or permitted, to take part in management. Female Visitors (who were allowed to visit patients at any time) were in fact accepted in Reed's time. In 1892, the Select Committee of the House of Lords (see above) considered that since the majority of patients at the RHI were female, a Ladies Committee should be appointed. But the appointment of ladies to management was vigorously opposed by the Management Committee; the president, the 5th Marquess of Northampton (1851-1913) was, however, in favour! Nevertheless, in 1898, a Ladies Visiting Committee was in fact set up, and in the same year Miss Georgiana Hill formally proposed that Ladies should be elected to the Board of Management. In the event, this was again vehemently opposed by the (all male) Board, and also perhaps surprisingly, by the Ladies Visiting Committee. Despite further efforts by Miss Hill, such a move was resisted until 1928, when Miss Thorne and Mrs Arnold were elected to the Board of Management. Now, almost half of the Board consists of women! Meanwhile the Lady Visitors have continued visiting, meet at regular intervals, and organise the annual sale of patients' work.

The Ladies Association was a committee (which ceased operation in 1943) outside the hospital; they collected money for the benefit of unbefriended candidates for election. The Association was founded by the 4th Marquess of Northampton (1818-97) and it had several distinguished women patrons, who included Lady Loch (Northampton's daughter), and Princess Christian (1846-1923), a daughter of Queen Victoria. ${ }^{3}$

\section{NATIONAL HEALTH SERVICE (NHS) ACT}

In 1946, shortly after the Second World War had ended, the NHS Act was passed through Parliament, with the intention of nationalising all hospitals throughout the land on the "appointed day", 5 July 1948. The Minister of Health was Aneurin Bevan (1897-1960), who saw no reason to exclude the RHHI from the NHS. However, the Board of Management considered that by losing their voluntary status, the RHHI would be deprived of its autonomy and individuality. Most of the other hospitals for incurables (many had by then been set up) shared this view. The first arbitration proceedings to be heard after a lengthy delay were those of the Home and Hospital for Jewish Incurables, at Tottenham. The arbitrator ruled entirely in that institution's favour-it being considered a home rather than a hospital. The RHHI's arbitration proceedings had a similar outcome in the wake of that of the Jewish home. This procrastination involved legal expenses, as well as a serious fall in subscriptions and legacies, during a period of great uncertainty. ${ }^{14}$

\section{FUNDRAISING AND ROYAL VISITS}

Several means of fundraising for this charity have already been alluded to. In 1868, for example, a meeting was held at Leamington at which Frederick Temple (1821-1902), Headmaster of Rugby and later Archbishop of Canterbury, made an appeal for funds for the hospital. The Christmas appeals became an annual event from 1872 until the Second World War (1939-45), about 30000 copies being circulated to subscribers and others. These were usually organised by the Secretary (either Andrew or Cutting), but outsiders were often called in to assist in writing a suitable text; these included the Reverend Paxton Hood, Mrs Oliphant, Miss Ruby Ayres, and Hesta Stretton. Newspaper advertisements were also a source of publicity. Then, there was broadcasting (the "week's good cause") and films. ${ }^{35}$ The Festival Dinner was a popular annual event during Victorian times. It was always held in the City, usually at one of the hotels or City companies and usually attended by 100 to 200 guests. An individual prominent in public life usually presided: Charles Dickens, the Duke of Argyll, Lord Malsbury, and Lord Justice Darling took part, but the Duke of Wellington and Sir Robert Peel declined! These dinners were given up during the Great War (1914-18) and substituted by Festival Lunches. ${ }^{3}$

The hospital has, over the last 150 years, attracted support from leading members of the aristocracy. In 1932, the RHHI received a visit from King George V and Queen Mary. In more recent times, there have been visits by, among others, HM the Queen; HM the late Queen Mother; the Prince of Wales; Diana, Princess of Wales; the Princess Royal, and many others.

\section{REFERENCES}

1 Anonymous. Notes and sketches illustrating the Royal Hospital for Incurables, West Hill, Putney Heath. London: RHI, 1881:23. 
2 French L. The Royal Hospital and Home for Incurables, Putney, and its founder. London: RHHI, 1936:40.

3 Maclagan ED. The Royal Hospital and Home for Incurables: three lectures delivered to the patients of the hospital on the 6th, 13th, and 27th November $1946: 5,9,10$

4 Stokes-Roberts AE. A short history of the Royal Hospital and Home for Incurables, Putney. London: RHHI, 1972:56.

5 Cook GC. Victorian incurables: a history of the Royal Hospital for NeuroDisability, Putney. Durham: The Memoir Club, 2004:272

6 Reed A, Reed C. Memoirs of the life and philanthropic labours of Andrew Reed, DD, with selections from his journals. 2nd Ed. London: Strahan \& Co, 1863:552.

7 May T. The Victorian workhouse. London: Shire Publications Ltd, 2002:32.

8 Morrison K. The workhouse: a study of poor-law buildings in England. Swindon: Royal Commission on the Historical Monuments of England, 1999:255.

9 Cook GC. Henry Currey, FRIBA (1820-1900): leading Victorian hospital architect, and early exponent of the "pavilion principle". Postgrad Med J 2002:78:352-9.

10 William John Little, SFRCP (1810-94) was born in the East End of London and received his medical education at the (Royal) London Hospital. As a child, he had contracted poliomyelitis which left him with a left sided talipes equinovarus. He founded the Orthopaedic Institution (later the Royal Orthopaedic Hospital) in 1839, and at the London Hospital he was elected assistant physician (1839) and physician (1845). In addition to his honorary appointment at the RHI, he held appointments at the Royal Orphan Asylum and the Asylum for Idiots.

11 William Munk, SFRCP (1816-98) was born at Battle, Sussex and received his medical education at University College, London, and Leyden University. $\mathrm{He}$ was physician to the smallpox hospital (1853-93), and held several honorary appointments, including that at the RHI. At the Royal College of Physicians, he was Harveian Librarian (1857 until his death), and published the first edition of what has come to be known as Munk's Roll in 1861. He was also the Senior Censor and Vice President of the College.

12 James Luke, FRCS, FRS (1799-1881) was born at Exeter and received his medical education at the (Royal) London Hospital; he had attended the lectures of John Abernethy and Sir Astley Cooper. He was elected Assistant Surgeon (1827), Surgeon (1833) and Consulting Surgeon (1861) to the London Hospital. At the Royal College of Surgeons, he was a Member of Council (1846-66), Vice President (1851, 52, 60 and 61), President (1853 and 62), and Hunterian Orator (1852). He was a pioneer in the surgery of strangulated hernia and cleft palate.

13 Cook GC, Webb AJ. Reactions from the medical and nursing professions to Nightingale's "reform(s)" of nurse training in the late 19th century. Postgrad Med J 2002;78:118-23.

14 Cook GC. Transfer of hospitals and "additional premises" to the State: questionable morality in the implementation of the National Health Service Act (1946). Postgrad Med J 2004 (in press).

\section{IMAGES IN MEDICINE}

\section{An unusual case of hirsutism}

\begin{abstract}
A 25 year old HIV positive woman presented with a progressive history of hirsutism (fig lA) unresponsive to oral contraceptives and cyproterone acetate. During the summer, bullous lesions appeared on the dorsal area of both hands (fig 1B). Laboratory studies disclosed the following values: plasma free testosterone $14 \mathrm{pmol} / \mathrm{l}$ (normal 2.4-12.5), DHEA-S $14 \mathrm{mmol} / \mathrm{l}$ (normal 1.1-9.2), alanine aminotransferase $65 \mathrm{UI} / \mathrm{l}$ (normal $<20$ ), aspartate aminotransferase $90 \mathrm{UI} / \mathrm{l}$ (normal <20), and alkaline phosphatase $116 \mathrm{UI} / \mathrm{l}$ (normal 28-36). A 24 hour urine collection showed raised concentrations of uroporphyrin (4908 $\mu \mathrm{g}$, normal <25), heptacarboxyporphyrin $(2030 \mu \mathrm{g}$, normal <7), hexacarboxyporphyrin (113 $\mathrm{g}$, normal <6), and pentacarboxyporphyrin $(264 \mu \mathrm{g}$, norma $<7)$. The coproporphyrin level was $136 \mu \mathrm{g}$ (normal $<110)$. Porphyria cutanea tarda is usually sporadic and caused by a diminution in the activity of liver uroporphyrinogen decarboxylase. The manifestations include a bullous dermatosis on sun-exposed areas, poikilodermatous scarred areas dotted with milia, hyperpigmentation, facial hypertrichosis, and often biochemical evidence of liver disease. ${ }^{12}$ Alcohol and oestrogens are known to be important precipitating agents. Few cases of porphyria cutanea tarda have been associated with HIV infection. ${ }^{3-5}$
\end{abstract}

P Maheux

Division of Endocrinology and Metabolism, Université de Sherbrooke, Canada
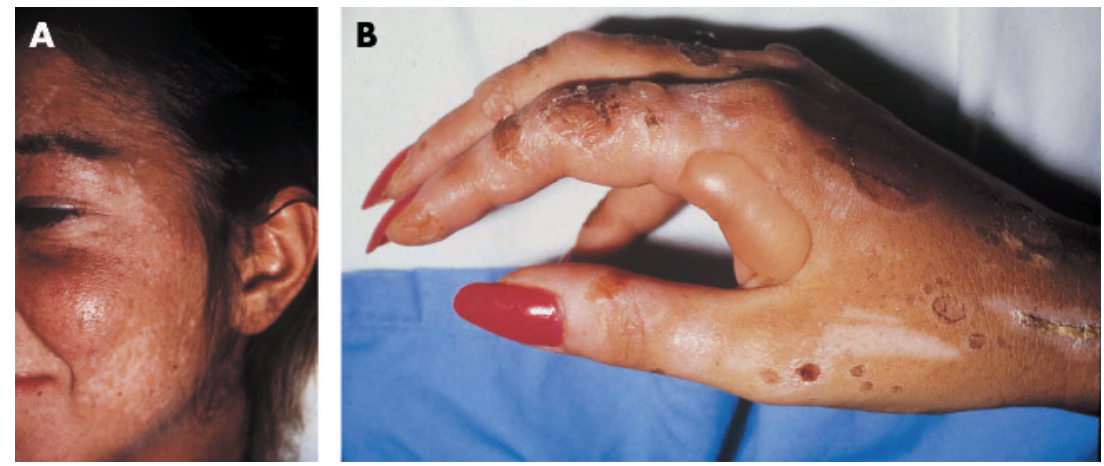

Figure 1 (A) Patient showing hirsutism on face and (B) bullous lesion on hand (published with permission).

L-G Ste-Marie, R Matte

Division of Endocrinology, Hôpital Saint Luc du Centre hospitalier de l'Université de Montréal, Canada

Correspondence to: Dr Pierre Maheux, Division of Endocrinology and Metabolism, Université de Sherbrooke, 3001-12th Avenue North, Sherbrooke, Québec, Canada J1H 5N4;

Pierre.Maheux@USherbrooke.ca

\section{REFERENCES}

1 Elder GH. Porphyria cutanea tarda. Semin Liver Dis 1998;18:67-75.

2 Thadani H, Deacon A, Peters T. Diagnosis and management of porphyria. BMJ 2000;320:1647-51.

3 Wissel PS, Sordillo $P$, Anderson KE, et al. Porphyria cutanea tarda associated with the acquired immune deficiency syndrome. Am J Hematol 1987;25:107-13.

4 Blauvelt A, Harris HR, Hogan DJ, et al. Porphyria cutanea tarda and human immunodeficiency virus infection. Int J Dermatol 1992;31:474-9.

5 O'Connor WJ, Badley AD, Dicken $\mathrm{CH}$, et al. Porphyria cutanea tarda and human immunodeficiency virus: two cases associated with hepatitis C. Mayo Clin Proc 1998;73:895-7. 